\title{
DOES AN EFFICIENT BUSINESS REGULATORY ENVIRONMENT MATTER AT URBAN LEVEL? SOME EVIDENCE FROM CHINESE CITIES
}

\author{
Alessandro MARRA, Vittorio CARLEI \\ University of Chieti, Pescara, Italy
}

\begin{abstract}
It is widely acknowledged that firms require an efficient regulatory environment: if transaction costs generated by business regulations are not onerous, firms grow more and develop more quickly, attract more foreign direct investment, and employ more workers. But what does it induce alterations in the basic institutional framework? In this paper we intend to test North's thesis by which as trade expands and the size of the market grows, transaction costs increase requiring that more and more resources should be devoted to improving existing regulations and, then, reducing such costs. The paper is structured as follows. Section 1 introduces. Section 2 provides the theoretical background. Section 3, based on World Bank data on 30 Chinese cities, investigates whether there is a correlation at urban and provincial levels between efficient business regulations on one side and economic outcomes (gross domestic product, foreign direct investment, employment, etc.) on the other. Section 4 addresses the pilot question mentioned above and tests whether simpler and less costly ways of meeting legal requirements for starting and running a business are associated with long-run trade. Section 5 discusses results in the light of theoretically assumed causal links and proposes a 2SLS regression model, whereby a geographical instrumental variable is used to investigate the causal relationship between business regulations and exports.
\end{abstract}

Key Words: business regulations, exports, income levels, urban level, China

\section{Introduction}

Nowadays there is a general consensus among economists that institutions (defined in North 1990 as "the rules of the game in a society" or "the humanly devised constraints that shape human interaction") are key determinants of countries' economic performances and help to explain prevailing patterns of prosperity and levels of GDP per capita (GDPpc) around the world.

Since the ground-breaking contributions by North and Thomas (1973) and North (1981), the impact of institutions on economic prosperity and growth has captured the interest of an increasing number of authors. All these authors inspired the research programs initiated by many institutions, including the World Bank, which started the major project, Doing Business, aimed at measuring transaction costs generated by business rules and administrative procedures applying to domestic small and medium-sized enterprises (SMEs). Nowadays, Doing Business is accepted as one the standard tools for quantifying the impact of regulations on economic activities. The goal underlying Doing Business is to corroborate the causal association between better institutions on one side and, respectively, economic prosperity and growth on the other based on statistical evidence: in this sense the statement in the report entitled Doing Business in 2006: Creating Jobs: "the indicators are used to analyze economic outcomes and identify what reforms have worked, where, and why" (Doing 
Business 2006, i).

To note that for better institutions the Doing Business team mean more efficient, in terms of generated transaction costs for firms, business rules and administrative procedures (such as completing business start-up formalities through a one-stop shop).

The reliance on such a theoretically assumed causal relationship between better institutions (i.e., more efficient business regulations) and economic outcomes implies the answer to a fundamental research question: What does it induce alteration in the basic institutional framework? We focus on a specific strand in the institutional theoretical frame. According to North (1991), as trade expands and the size of markets grows, transaction costs increase requiring that more and more resources should be devoted to improving existing regulations and, then, reducing such costs.

The paper is structured as follows. Section 1 introduces. Section 2 provides the theoretical background. Section 3, based on World Bank data on 30 Chinese cities, investigates whether there is a correlation between efficient business regulations on one side and, respectively, income levels and rates, exports, FDI and employment on the other. As far as we know there are not so many attempts to test such a correlation at urban and provincial levels. Section 4 addresses the pilot question mentioned above and tests whether simpler and less costly ways of meeting legal requirements for starting and running a business are associated with longrun trade: we proxy long-run trade in Chinese cities with the volume of urban level exports, estimated using a location quotient approach per number of employees in the manufacturing sector. Section 5 discusses correlations among our three sets of variables (long-run trade, business regulations and income levels) in the light of theoretically assumed causal links and proposes a 2SLS model between business regulations (dependent) and exports (independent) making use of a geographical variable (the inverse of closeness to sea of each capital times the number of ports in the related province) as instrument. Attempting to estimate the causal effect of exports on business regulations, we derive that the geographical variable affects the latter only through its effect on the former. If the inverse of closeness to sea times the number of ports only affects rules because it affects exports (holding other variables in the model fixed), correlation between the geographical variable and business rules is evidence that exports cause changes in the business regulatory environment. Our results, though preliminary and somehow speculative (lacking a larger dataset), intend to add to the literature on institutions and economic outcomes.

\section{The theoretical background}

As stated by Acemoglu et al. (2001: 1369) developed countries with "better institutions, more secure property rights and less distortionary policies will invest more in physical and human capital, and will use these factors more efficiently to achieve a greater level of income" (in this sense, see also Jones 1981).

This view has received wide support from several cross-country studies investigating the correlation between institutions and aggregate incomes (see Hall and Jones 1999; Easterly and Levine 2003; Rodrik, Subramanian and Trebbi 2004). Since it is likely that rich economies choose or can afford better institutions, these latter constitute both the cause and the result of income levels. Nonetheless, as well stated by Rodrik (2004): "Institutions are causal in the sense that a poor country that is able to revise the rules of the game in the direction of strengthening the property rights of entrepreneurs and investors is likely to experience a lasting 
increase in its productive capacity" (Rodrik 2004: 1).

Beyond the studies which have shown that institutions are associated to countries' prosperity, there are many researchers who concentrated on the link between institutions and economic growth (see, inter alia, Djankov et al. 2006, Stel et al. 2007, Ardagna and Lusardi 2008, Aldashev 2009).

In the late 1990s, while investigating the development of financial markets, La Porta et al. (1998) identified and constructed three blocks of variables: quality of countries' legal frameworks, development of financial markets and growth of economies. Assuming that the US model is the benchmark for "good" financial markets, and that extensive financial markets produce growth, the authors found a significant and positive correlation between the quality of countries' legal frameworks and economic growth. Since then interest in the impact of regulation on growth rates has increased: Djankov et al. (2002), for example, found that while the total cost of opening a medium-size business vary greatly among countries: for example, in 1999 this total cost was less than $0.02 \%$ of national GDPpc in the United States and around 4.95\% in the Dominican Republic (see also Djankov et al. 2003; Botero et al. 2004; La Porta et al. 2006).

In 2003 La Porta, Lopez de Silanes, Shleifer, Vishny, and Djankov (the creator of the Doing Business project) transformed the model into a more general theory and published "The New Comparative Economics". In this work, the authors assumed a strict relationship between good rules and economic development and deduced that countries lacking protection for investors (because of weak legal rules or poor enforcement of rules) would suffer economically.

All these articles inspired the research program Doing Business by the World Bank. Its aim is to confirm the association between better institutions (meant as more efficient business regulations) on one side and, respectively, economic prosperity and growth on the other based on statistical evidence. Understanding the relevance of institutions on economic outcomes implies the answer to a fundamental research question: What does it induce alteration in the basic institutional framework?

According to North (1991), as trade expands and the size of markets grows, transaction costs increase requiring that more and more resources should be devoted to improving existing regulations and, then, reducing such costs. This thesis is rooted in the 1950s, when North (1955) suggested that the economic growth of a region is tied to the success of its export trade (he criticised the literature on the sequence of development stages in a region and stressed the relevance of exports). Several decades later North (1991) makes use of the concept of export base to emphasise the role of institutional structures based on reasoning related to the several stages of development in a local community. North (1991) starts with local exchanges in a village: in this context specialization is very low because most individuals are self-sufficient; an ensemble of informal social constraints determines low transaction costs which enable trade on a village scale. As specialisation increases and the size of the market grows beyond the single village the informal social network is replaced, and possibilities for conflicts over exchanges, and transaction costs, increase. In this stage of development, more resources are required to measure and enforce transactions. In North's (1991: 99) words:

"The growth of long distance trade poses two distinct transaction cost problems. One is a classical problem of agency, which historically was met by use of kin in long-distance trade 
As the size and volume of trade grew, agency problems became an increasingly major dilemma. A second problem consisted of contract negotiation and enforcement in alien parts of the world, where there is no easily available way to achieve agreement and enforce contracts. Enforcement means not only such enforcement of agreements but also protection of the goods and services en route from pirates, brigands, and so on".

North (1991: 100) concludes reasoning by underlining the need for formal rules:

"Such societies need effective, impersonal contract enforcement, because personal ties, voluntaristic constraints, and ostracism are no longer effective as more complex and impersonal forms of exchange emerge. It is not that these personal and social alternatives are unimportant; they are still significant even in today's interdependent world. But in the absence of effective impersonal contracting, the gains from "defection" are great enough to forestall the development of complex exchange".

North (1991: 109) provides the example of the Champagne Fairs (as representing longdistance trade in Europe) to show how some communities evolve from less complex to more complex forms of exchange:

"while a merchant at a medieval European Fair would certainly gain from acquiring [better information on opportunities and having greater bargaining skills than other traders, since profitable opportunities came from being better informed and being a more skilled bargainer than other traders], he would gain also from devising ways to bond fellow merchants, to establish merchant courts, to induce princes to protect goods from brigandage in return for revenue, to devise ways to discount bills of exchange. His investment in knowledge and skills would gradually and incrementally alter the basic institutional framework. Note that the institutional evolution entailed not only voluntary organizations that expanded trade and made exchange more productive, but also the development of the state to take over protection and enforcement of property rights as impersonal exchange made contract enforcement increasingly costly for voluntary organizations which lacked effective coercive power".

At this stage it is useful to illustrate the adopted notion of institutions and our proposed extension to North's thesis. First, in this paper institutions are business rules and administrative procedures related to starting a business, registering property, getting credit and enforcing contracts. Secondly, we share the view by which long-run trade implies more chances of conflicts, agency problems, commercial risks and uncertainty for firms: if this is true, public authorities need to activate for the provision of a more efficient business regulatory environment in order to compensate for the higher transaction costs which typically arise when business develops outside the urban or provincial borders. In other words, where long-run trade is high public authorities need to assist firms more efficiently generating lower transaction costs through adopted rules and procedures (i.e., one stop shop process for business start-up formalities; less expensive bureaucratic procedures; and so on).

\section{Transaction costs, business regulations and economic performance in Chinese cities}

The research project Doing Business in China 2008 provides quantitative measures of business regulations for SMEs in 30 Chinese cities in four areas or items: starting a business, registering property, getting credit (creating and registering collateral) and enforcing contracts. 
In order to make data comparable across cities and/or countries, the Doing Business team studied a specific type of company - generally a limited liability company. In constructing indicators, the team assumes that entrepreneurs are knowledgeable about and comply with the regulations in place, although, in practice, entrepreneurs might decide to either become formal entities (spending time finding out where to go and what documents to submit) or remain in the informal economy (e.g. avoiding legally required procedures by not registering their property).

Doing Business encompasses two types of data: the first come from readings of laws and regulations; the second are "time and motion" indicators that measure the efficiency of achieving a regulatory goal. The time and motion indicators record cost estimates from official fee schedules where applicable. This builds on Hernando de Soto's work which applies this approach to show the obstacles to setting up a garment factory in the periphery of Lima in the 1980s. Some of the Doing Business indicators give higher scores for simpler and less costly ways of meeting legal requirements for starting and running a business.

The subnational Doing Business report on China captures differences in business regulations across 30 different cities: 22 provincial capitals (Hefei, Fuzhou, Lanzhou, Guangzhou, Guiyang, Haikou, Shijiazhuang, Harbin, Zhengzhou, Wuhan, Changsha, Nanjing, Nanchang, Changchun, Shenyang, Hangzhou, Xi'an, Jinan, Taiyuan, Chengdu, Kunming and Xining), 4 capitals of autonomous regions (Urumqi, Nanning, Yinchuan and Hohhot, respectively for Xinjiang, Guangxi, Ningxia and Inner Mongolia) and the 4 large municipalities of Beijing, Shanghai, Tianjin and Chongqing. For each of these cities, Table 1 presents the following information: number of procedures, number of days, costs (as a percentage of GDPpc in the location) and minimum capital investment (as a percentage of GDPpc) required to start a new business; number of procedures, number of days, costs (as a percentage of property value) required to register a property; number of days and costs of setting up a credit guarantee (calculated as a percentage of the loan value); number of procedures, number of days and costs (as a percentage of the debt) to enforce a contract.

Measured by the above indicators, coastal cities perform better than cities in other geographic regions. According to the methodology used by Doing Business, rankings are calculated by ordering the resulting average of the percentile rankings of each city for each of the four items (starting a business, registering property, getting credit, and enforcing a contract). The rankings for each item are based on the simple average of the percentile rankings of its component indicators: thus, the ranking for "starting a business" is an average of the city's ranking for number of procedures, number of days, costs and minimum capital requirement to register a business (on the methodology, see Djankov et al. 2004). In short, lower values of the percentile rankings would indicate more efficient business rules and administrative procedures: to bear in mind that in what follows we multiply times -1 to get higher values for more efficient regulations. For example, the Province of Jiangsu (Najisung City) in the southeast scores 0.04 in the percentile ranking for ease of starting a business (then, in our empirical investigation it becomes -0.04), 0.19 for ease of registering the property $(-0.19), 0.03$ for obtaining credit $(-0.03), 0.07$ for contract enforcement $(-0.07)$, giving an overall 0.09 for ease of doing business in China (-0.09), making it the best performer in China.

We test the thesis underlying Doing Business: when business regulations are particularly onerous, in terms of time and cost, the size of the informal sector grows. Informal activity implies that firms typically grow less and grow more slowly, attract less FDI, employ fewer workers, and so on. We use urban level data and link some basic economic indicators 
Alessandro MARRA, Vittorio CARLEI

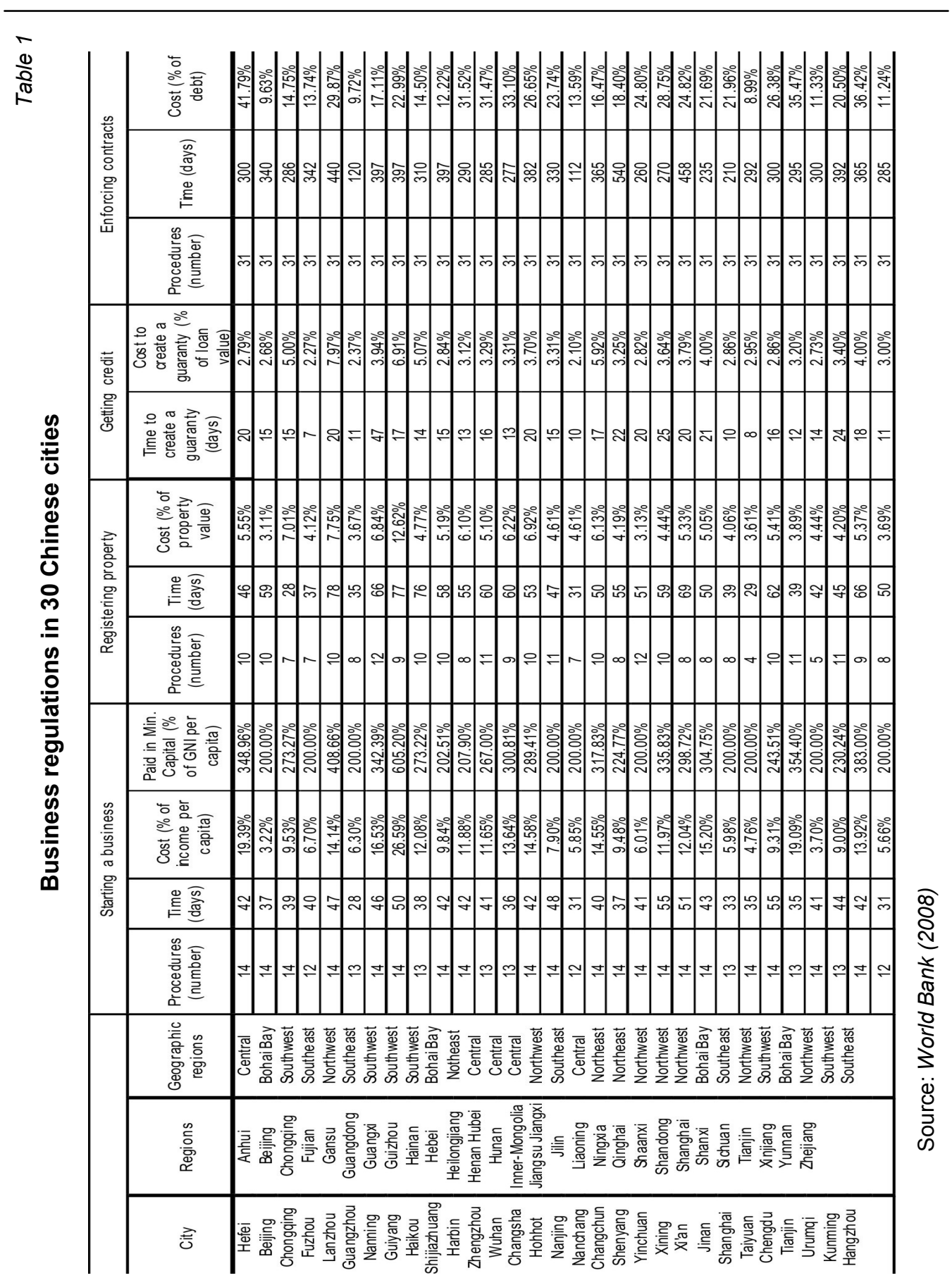



from Chinese City

(logarithmic transformations of, respectively, income levels, growth rates, FDI and employment) to institutional performance, meant as more efficient business regulations (see Table 4). For institutional performance, we average the percentile rankings for each item, that is, the average of the percentile rankings of the component indicators times -1 (see last column in Table 2).

Table 2

Institutional variables in Chinese cities: percentile rankings for each area

\begin{tabular}{|c|c|c|c|c|c|c|}
\hline $\begin{array}{l}\text { Region } \\
\text { (province) }\end{array}$ & City & $\begin{array}{l}\text { Ease of starting } \\
\quad \text { a business } \\
\text { (percentile) }\end{array}$ & $\begin{array}{c}\text { Ease of } \\
\text { regist ering } \\
\text { property } \\
\text { (percentile) } \\
\end{array}$ & $\begin{array}{c}\text { Ease of } \\
\text { getting credit } \\
\text { (percentile) }\end{array}$ & $\begin{array}{c}\text { Ease of } \\
\text { enforcing } \\
\text { contracts } \\
\text { (percentile) } \\
\end{array}$ & $\begin{array}{c}\text { Ease of doing } \\
\text { business in } \\
\text { China } \\
\text { (percentile) }\end{array}$ \\
\hline Anhui & Hefei & 0.68 & 0.52 & 0.43 & 0.48 & $(-) 0.53$ \\
\hline Beijing & Beij ing & 0.15 & 0.39 & 0.24 & 0.22 & $(-) 0.25$ \\
\hline Chongqing & Chongqing & 0.43 & 0.33 & 0.62 & 0.21 & $(-) 0.40$ \\
\hline Fujian & Fuzhou & 0.16 & 0.15 & 0.02 & 0.30 & $(-) 0.16$ \\
\hline Gansu & Lanzhou & 0.72 & 0.83 & 0.84 & 0.57 & $(-) 0.74$ \\
\hline Guangdong & Guangzhou & 0.09 & 0.13 & 0.10 & 0.03 & $(-) 0.09$ \\
\hline Guangxi & Nanning & 0.72 & 0.88 & 0.88 & 0.40 & $(-) 0.72$ \\
\hline Guizhou & Guiyang & 0.81 & 0.79 & 0.78 & 0.46 & $(-) 0.71$ \\
\hline Hainan & Haikou & 0.40 & 0.64 & 0.60 & 0.28 & $(-) 0.48$ \\
\hline Hebei & Shijiazhuang & 0.43 & 0.57 & 0.31 & 0.33 & $(-) 0.41$ \\
\hline Heilongjiang & Harbin & 0.46 & 0.49 & 0.33 & 0.40 & $(-) 0.42$ \\
\hline Henan & Zhengzhou & 0.40 & 0.70 & 0.52 & 0.36 & $(-) 0.49$ \\
\hline Hubei & Wuhan & 0.42 & 0.65 & 0.40 & 0.37 & $(-) 0.46$ \\
\hline Hunan & Changsha & 0.59 & 0.64 & 0.69 & 0.49 & $(-) 0.60$ \\
\hline Inner-Mong olia & Hohhot & 0.38 & 0.53 & 0.48 & 0.39 & $(-) 0.45$ \\
\hline Jiangsu & Nanjing & 0.04 & 0.19 & 0.03 & 0.07 & $(-) 0.09$ \\
\hline Jiangxi & Nanchang & 0.57 & 0.56 & 0.76 & 0.34 & $(-) 0.56$ \\
\hline Jilin & Chang chun & 0.35 & 0.33 & 0.69 & 0.47 & $(-) 0.46$ \\
\hline Liaoning & Shenyang & 0.25 & 0.49 & 0.45 & 0.25 & $(-) 0.36$ \\
\hline Ningxia & Yinchuan & 0.67 & 0.51 & 0.81 & 0.31 & $(-) 0.57$ \\
\hline Qinghai & Xining & 0.64 & 0.56 & 0.71 & 0.54 & $(-) 0.61$ \\
\hline Shaan $x i$ & Xi'an & 0.66 & 0.36 & 0.83 & 0.20 & $(-) 0.51$ \\
\hline Shandong & Jinan & 0.09 & 0.18 & 0.19 & 0.20 & $(-) 0.17$ \\
\hline Shanghai & Shanghai & 0.14 & 0.03 & 0.19 & 0.13 & $(-) 0.12$ \\
\hline Shan xi & Taiyuan & 0.54 & 0.67 & 0.40 & 0.38 & $(-) 0.50$ \\
\hline Sichuan & Chengdu & 0.52 & 0.39 & 0.33 & 0.45 & $(-) 0.42$ \\
\hline Tianj in & Tianjin & 0.21 & 0.22 & 0.22 & 0.20 & $(-) 0.21$ \\
\hline Xinjiang & Urumqi & 0.41 & 0.47 & 0.78 & 0.41 & $(-) 0.52$ \\
\hline Yunnan & Kunming & 0.64 & 0.63 & 0.72 & 0.55 & $(-) 0.64$ \\
\hline Zhejiang & Hangzhou & 0.03 & 0.23 & 0.26 & 0.11 & $(-) 0.16$ \\
\hline
\end{tabular}

Source: World Bank (2008)

Table 3 shows data on the economic performance of Chinese provinces, autonomous regions and large municipalities: GDP (expressed in 100 millions of yuan) at year 2008, "GDP"; GDP per capita (yuan per person) at year 2008, "GDPpc"; Primary Industry Percentage (expressed in 100 millions of yuan), "I ind"; Secondary Industry Percentage (expressed in 100 millions of yuan), "Il ind"; Tertiary Industry Percentage (expressed in 100 millions of yuan), "III ind"; Variation on percentage of GDP per capita between 1996 and 2008, " $\Delta$ GDPpc"; Amount of foreign capital utilised (expressed in USD 10,000s) in 2007, "FC"; Employment (in 10,000 of persons) at 2007, "Emp".

We estimate the degree of association between the variables in terms of their linear dependence. We do not assume any aprioristic cause-and-effect relationship between them. 
Alessandro MARRA, Vittorio CARLEI

GDP, FDls and employment in 30 Chinese cities

Table 3

\begin{tabular}{|c|c|c|c|c|c|c|c|c|c|}
\hline $\begin{array}{c}\text { Region } \\
\text { (province) }\end{array}$ & GDP & $\Delta \mathrm{GDP}$ & I ind & Il ind & II ind & GDPpc & Emp & $\Delta \mathrm{GDPpc}$ & FC \\
\hline Anhui & $8,874.17$ & 1.205 & $1,418.08$ & $4,137.35$ & $3,318.74$ & $14,485.00$ & 28.437 & 1.203 & $299,892.0$ \\
\hline Beijing & $10,488.05$ & 1.121 & 112.83 & $2,693.15$ & $7,682.07$ & $63,029.00$ & 335.371 & 1.083 & $506,572.0$ \\
\hline Chongqing & $5,096.66$ & 1.236 & 575.4 & $2,433.27$ & $2,087.99$ & $18,025.00$ & 132.597 & 1.230 & $122,011.0$ \\
\hline Fujian & $10,823.11$ & 1.170 & $1,157.75$ & $5,415.77$ & $4,249.59$ & $30,123.00$ & 58.652 & 1.163 & - \\
\hline Gansu & $3,176.11$ & 1.175 & 463 & $1,471.43$ & $1,241.68$ & $12,110.00$ & 38.587 & 1.171 & $38,202.0 C$ \\
\hline Guang dong & $35,696.46$ & 1.148 & $1,970.23$ & $18,402.64$ & $15,323.59$ & $37,589.00$ & 143.912 & 1.134 & $1,961,771.1$ \\
\hline Guangxi & $7,171.58$ & 1.204 & $1,453.90$ & $3,037.74$ & $2,679.94$ & $14,966.00$ & 36.962 & 1.192 & $94,396.0 \mathrm{C}$ \\
\hline Guizhou & $3,333.40$ & 1.216 & 547.85 & $1,408.71$ & $1,376.84$ & $8,824.00$ & 37.185 & 1.276 & $\overline{15,333.0 C}$ \\
\hline Hainan & $1,459.23$ & 1.193 & 437.61 & 434.4 & 587.22 & $17,175.00$ & 14.080 & 1.180 & $112,499.0$ \\
\hline Heibei & $16,188.61$ & 1.181 & $2,034.60$ & $8,777.42$ & $5,376.59$ & $23,239.00$ & 50.118 & 1.169 & $300,722.0$ \\
\hline Heilongjiang & $8,310.00$ & 1.176 & $1,089.10$ & $4,365.90$ & $2,855.00$ & $21,727.00$ & 100.800 & 1.176 & $216,908.0$ \\
\hline He'nang & $18,407.78$ & 1.226 & $2,658.80$ & $10,477.92$ & $5,271.06$ & $19,593.00$ & 42.562 & 1.224 & - \\
\hline Hubei & $11,330.38$ & 1.227 & $1,780.00$ & $4,963.61$ & $4,586.77$ & $19,860.00$ & 112.146 & 1.225 & - \\
\hline Hu'nan & $11,156.64$ & 1.213 & $2,007.40$ & & 4,2 & $17,521.00$ & 51.409 & 1.209 & $356,400.0$ \\
\hline Inner Mongolia & $7,761.80$ & 1.274 & 906.98 & $4,271.03$ & $2,583.79$ & $32,214.00$ & 12.406 & 1.269 & $238,780.0$ \\
\hline Jiangsu & $30,312.61$ & 1.178 & $2,100.00$ & $16,663.81$ & $11,548.80$ & $39,622.00$ & 57.802 & 1.168 & - \\
\hline Jiangxi & $6,480.33$ & 1.178 & $1,060.38$ & $3,414.88$ & $2,005.07$ & $14,781.00$ & 34.501 & 1.170 & - \\
\hline Jilin & $6,424.06$ & 1.216 & 916.7 & $3,064.63$ & $2,442.73$ & $23,514.00$ & 63.485 & 1.213 & $227,062.0$ \\
\hline Liaoning & $13,461.57$ & 1.221 & $1,302.00$ & $7,512.11$ & $4,647.46$ & $31,259.00$ & 68.617 & 1.215 & $909,673.0$ \\
\hline Ning xia & $1,098.51$ & 1.235 & 120 & 581.24 & 397.27 & $17,892.00$ & 8.357 & 1.221 & $16,968.0 \mathrm{C}$ \\
\hline Qinghai & 961.53 & 1.227 & 105.58 & 529.4 & 326.55 & $17,389.00$ & 9.271 & 1.220 & - \\
\hline Shaanxi & $6,851.32$ & 1.253 & 753.72 & $3,842.08$ & $2,255.52$ & $18,246.00$ & 91.819 & 1.249 & $119,516.0$ \\
\hline Shandong & $31,072.06$ & 1.197 & $3,002.65$ & $17,702.17$ & $10,367.23$ & $33,083.00$ & 78.876 & 1.190 & - \\
\hline Shanghai & $13,698.15$ & 1.124 & 111.80 & $6,235.92$ & $7,350.43$ & $73,124.00$ & 252.816 & 1.102 & $792,000.0$ \\
\hline Shanxi & $6,938.73$ & 1.210 & 302.48 & $4,265.77$ & $2,370.48$ & $20,398.00$ & 21.460 & 1.204 & $191,471.0$ \\
\hline Sichuan & $12,506.25$ & 1.190 & $2,366.15$ & $5,790.10$ & $4,350.00$ & $15,378.00$ & 87.959 & 1.193 & $201,169.0$ \\
\hline Tianjin & $6,354.38$ & 1.258 & $122: 58: 00$ & $3,821.07$ & $2,410.73$ & $55,473.00$ & 135.576 & 1.203 & $546,033.0$ \\
\hline Xinjiang & $4,203.41$ & 1.193 & 691.1 & $2,086.74$ & $1,425.57$ & $19,893.00$ & 18.796 & 1.170 & - \\
\hline Yunnan & $5,700.10$ & 1.202 & $1,020.94$ & $2,451.09$ & $2,228.07$ & $12,587.00$ & 49.587 & 1.194 & $55,233.0 \mathrm{C}$ \\
\hline Zhejiang & $21,486.92$ & 1.144 & $1,095.43$ & $11,580.33$ & $8,811.17$ & $42,214.00$ & 97.637 & 1.128 & $1,432,049.1$ \\
\hline
\end{tabular}

Source: China Data Online (2010), at chinadataonline.org

Table 4

Correlation between institutional variables and economic indicators*

\begin{tabular}{|llccc|}
\hline & GDP & I ind & II ind & III ind \\
\hline Ease Doing Business in China & 0.655 & -0.049 & 0.642 & 0.698 \\
\hline & GDPpc & $\Delta$ GDPpc & FC & Emp \\
\hline Ease Doing Business in China & 0.868 & -0.548 & 0.835 & 0.583 \\
\hline${ }^{*}$ Log transformation & \multicolumn{4}{r}{} \\
\hline
\end{tabular}

The degree of association between the degree of transaction costs generated by business regulations (i.e., institutional performance) and GDP, GDPpc, II ind (manufacturing), III ind (services), FC (our proxy for FDI) is strong. Such results provide preliminary evidence in support of the underlying assumption in Doing Business: firms typically grow more (GDP, GDPpc), attract more FDI and employ more workers (Emp) in the presence of lower transaction costs associated to legal requirements for starting and running a business. As expected, the secondary and tertiary sectors of the economy are crucial for similar analyses. In some cases the correlation values are considerably low or irrelevant: for example, for the association between institutional performance and, respectively, Emp (employment) and I ind (primary industry).

Note in Figure 1 the shape of the fitted lines of correlations between institutional performance 
and, respectively, logarithms of GDP and Emp. If we take the latter variables as our dependent variables and the institutional percentile rankings as explaining the simple regressions, then exponential, rather than linear models would produce slightly better results in terms of goodness of fit.

The shape of the fitted lines suggests the existence of a higher association between institutional variables and economic performance in those cities that perform better in terms of business regulations: this element becomes relevant when we discuss about exports in section 4 .

This interpretation finds further support in the fact that the four large municipalities of Beijing, Shanghai, Tianjin and Chongqing get high values of the ease of doing business but relatively low values of GDP. This is because the levels of GDP in these municipal areas (calculated on the municipal scale) are lower than in the larger areas, such as provinces and autonomous regions (calculated at provincial or regional levels). If we consider that manufacturing represents a large share of the Chinese economy, this is no surprise: we can assume that the bigger the geographic area that we consider, the higher is the number of firms and the level of GDP in that area. Adjusting for such a circumstance allows to provide stronger empirical support.

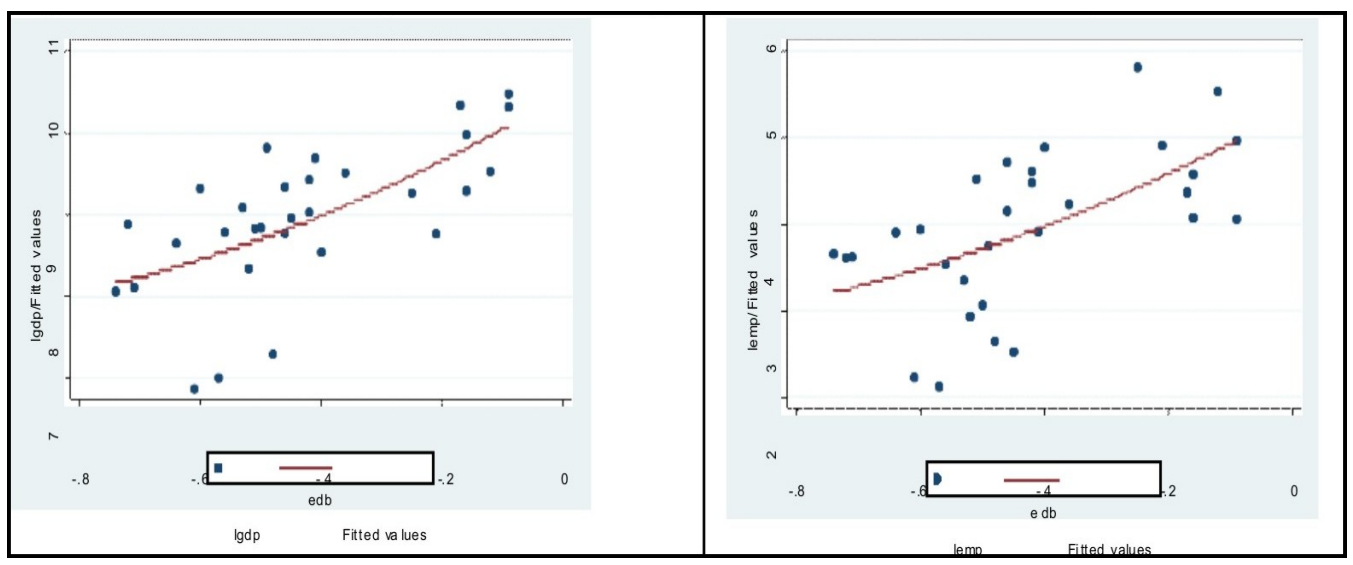

Fig.1 - Business regulations and logarithms of GDP and Emp

It is somewhat unexpected the negative correspondence between business regulations and variation in the percentage of GDPpc between 1996 and 2008 (- 0.548). Djankov et al. (2006), for example, suggest that countries with better business regulations grow faster: according to these authors moving from the worst quartile of business regulation to the best implies a 2.3 percentage point increase in annual growth ${ }^{1)}$.

How do we explain such poor results with regards to Chinese cities? In all evidence the catchup effect is strong. As well known, GDPpc increases at a faster rate in developing areas than in developed ones. Thus, all regional economies should eventually converge. One reason to expect this effect to take place is that workers in poor regions have little access to capital, so

1) Note that the tests carried out by Djankov et al. (2006) provide a very poor indication that business regulations are statistically associated to the rate of growth of GDPpc: the R-squared is surprisingly low, with a value of 0.09 for the basic regression model. 
their productivity is generally low; huge gains in productivity would result from only a small increase in the amount of capital. Otherwise, developed areas (with high levels of capital and high levels of productivity) would enjoy much smaller gains from similar increases in capital.

To discern the impact of more efficient business regulations on the rates of urban and regional growth it would have been useful to have a longer time series, across several decades, and information on further variables. However, the quite recent transition from a planned to a mixed economy does not allow for a historical inquiry into the interdependence between institutional change and economic outcomes at urban and provincial levels.

\section{Trade, market size and better institutions}

But what does it induce alterations in the basic institutional framework? To North long-run trade plays a major role. In our view, the answer to such a research question might shed some light on the causal relationship between institutions and economic performance.

According to the export-base framework, a region's economic activities fall into two broad categories: those related to production for the export market, and those that produce for the local market. The prosperity of a geographic area depends on the success of the former (North 1955). Theoretically, activities related to export constitute the export-base, that is, the major autonomous variable determining the level of regional GDP. Given these (basic or) export activities, the level of (non-basic or) domestic activities follows. At an applied level, two kinds of limitations need to be considered: one is related to the methodology ${ }^{2}$, the other is related to the geographical dimension. There is unanimous agreement that the significance of exports to explain regional income levels depends also on the size of the region. For example, in large regions with high levels of internal trade the quantitative relevance of exports decreases. Therefore, it is fundamental to define functional economic areas: areas with well-defined metropolitan cores, surrounded by non-metropolitan areas (see Beyers 2005) ${ }^{3}$. We use the administrative municipality as the level of aggregation to define the export-base of Chinese cities.

Exports of Chinese cities represent a good proxy for long-run trade. Several methods are available to estimate exports: the assumption method, the location quotient (LQ) approach, and the minimum requirements approach ${ }^{4}$. For the purpose of this paper we use LQ and data on employment estimated for 14 industries at the urban level ${ }^{5}$. We are aware of the

2) Exports are not the most important autonomous variable determining regional income: business investment, government expenditure and the volume of residential construction represent fundamental levers.

3) In his work on the economic base of regional economies in the United States, Beyers aggregates the 3,141 counties into 172 regions, most of which have a metropolitan core and a nonmetropolitan periphery.

4) Our location quotient approach (LQ) develops around the interpretation of this ratio: $L Q=$ $($ eim $/ \mathrm{em}) /($ Ein $/$ En), where eim $=$ employment in industry $\mathrm{i}$ at municipal level; em = total employment at municipal level; Ein = employment in industry $i$ at national level (the benchmark); En = total employment at national level.

5) The 14 sectors are (within parentheses the abbreviation used in Table 6): Farming, Forestry, Animal Husbandry, Fishery (LQ1); Mining and Quarrying (LQ2); Manufacturing (LQ3); Electric Power, Gas and Water Production and Supply (LQ4); Construction (LQ5); Transportation, Storage, Post and Telecommunications (LQ6); Wholesale \& Retail Trade (LQ7); Banking and Insurance (LQ8); Real Estate (LQ9); Social Services (LQ10); Public Management and Social Organization (LQ11); Scientific Research, 
growing contribution of the tertiary sector (services) to the export-base: Beyers and Alvine (1985) show within producer services the strength of the traded component, and it is now recognised that many lines of services are based on demand from both local clients and those located at a distance. However, this applies less to Chinese cities where the relevance of the secondary industry is unquestionable: the sum of all the location quotients calculated at the urban level for manufacturing shows the highest scores as 89,363 compared to 7,754 for "Transportation, Storage, Posts and Telecommunications", 48,912 for "Wholesale \& Retail Trade" and 54,061 for "Banking and Insurance".

Therefore, lacking a more detailed classification of "producer services" (those service activities with a more developed traded component, see Beyers 2005) we include "Manufacturing" (LQ3) in the calculation of the LQs (this choice is consistent with several studies on China's industrial structure and exports).

Exports are positively correlated to GDP ( $r$ is 0.648) and to our institutional variable ( $r$ is 0.532). As mentioned above, the shape of the fitted lines between the potential for manufacturing exports (LQ3) and, respectively, GDP and business regulations, would suggest the use of quadratic, rather than simple linear, regression models. In Figure 2 we excluded the outliers of Hainan, Ningxia and Qinghai with very low GDP levels. We also observe that a higher coefficient of correlation between exports and GDP might be obtained by considering that the four large municipalities present relatively lower income values (below the fitted line) compared to larger (provincial or regional) areas.

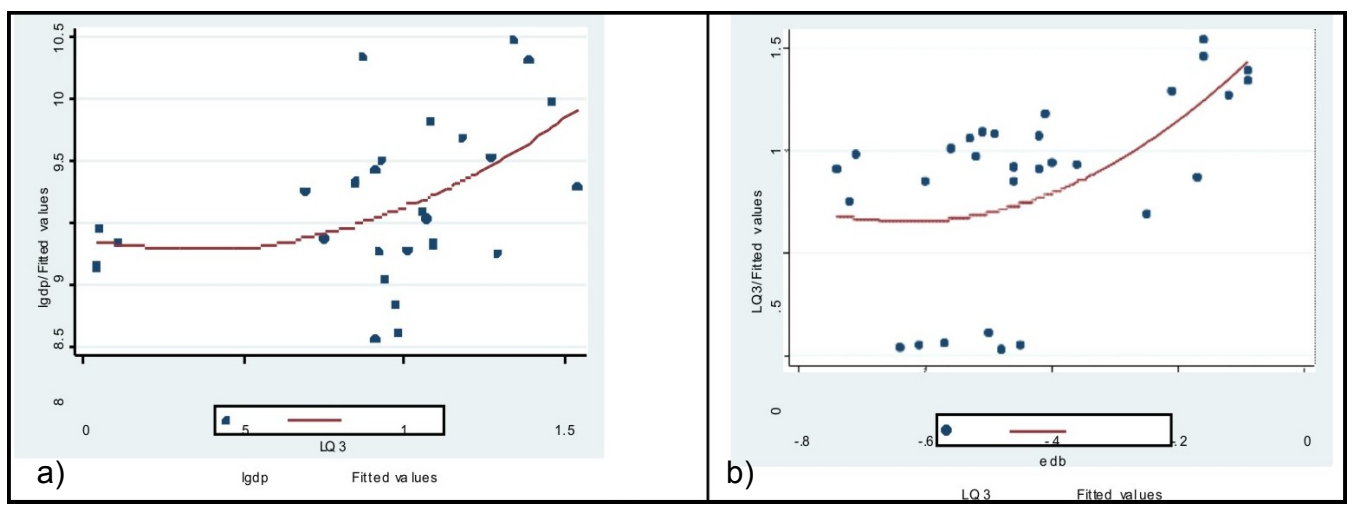

Fig. 2 - Exports and GDP, and business regulations quadratic

Moreover, there is a cluster of outliers, which include the areas of Qinghai, Yunnan, Ningxia, Inner Mongolia, Hainan and Shanxi. These areas are located predominantly in the centre of China, have poor business regulations and low performance at the urban level in terms of exports: omitting these observations, the correlation coefficient of exports and business regulations increases to 0.625 .

The fact that exports are correlated to efficient business regulations is in line with evidence in McMillan and Woodruff (1999): according to these authors firms are more likely to make use of better institutions (in their study, written contracts to protect transactions) when their customers

Technical Service and Geologic Prospecting (LQ12); Management of Water Conservancy, Environment and Public Facilities (LQ13); Health, Social Security and Social Welfare (LQ14). 
are located distantly. Also Hu and Qiu (2010) corroborate such a result by finding that Chinese firms with a considerable percentage of business outside their main location are more likely to use formal contracts.

Is this a preliminary finding in favour of the North's thesis about induced alterations in the institutional framework of a certain agglomeration? Of course, we use the current level of exports as proxy for the initial capacity of the urban agglomerations to trade on the long-run. As mentioned in section 1 coastal cities perform better, in terms of business regulations, than cities in other geographic regions. In the next section we make use of this information to add a geographical variable, the inverse of closeness to sea times the number of ports, to investigate the causal relationship between business regulations and income levels.

\section{Discussion of results}

We have provided some correlations, pure "symmetric" relationships, and tested the following statements:

- exports are positively associated to economic performance (i.e., to logarithm of GDP; $r_{\text {exp-eco }}$ $=0.648$;

- business regulations are positively associated to economic performance (including GDP levels ( $r_{\text {inst-eco }}=0.655$ ), amount of FDI, levels of formal employment, and so on);

- exports are positively associated to institutional performance $\left(r_{\text {exp-inst }}=0.532\right.$ or 0.625$)$.

Next we concentrate on the correlation between exports and GDP to provide some insights on the central role of business regulations. Once we ascertained the existence of a link also between exports and institutional variables, we became suspicious about the first correlation: What can we conclude about the relationship between exports and GDP? The coefficient of correlation between exports and GDP (oberved at the local level) is different from zero and significant $(0.648)$. According to the export-base frame, regional long-run growth depends on the success of its exports. However, we might suspect that the coefficient of correlation could derive from "spurious" causes. We thus introduce our third variable, institutional performance, and conjecture that it might account for the observed correlation between exports and GDP.

We compute the partial correlation between exports and GDP, with the institutional variable held constant, and compare it with the zero-order correlation: since the former is significantly lower ( $r_{\text {exp-eco.inst }}=0.469$ ) and the latter is not, we could conclude: a) that institutions are an intervening variable (the supposed causal effect of exports on GDP operates through business regulations), or b) that rexp-eco results from the hypothesized joint causal effect of institutions on both (exports and GDP) and, hence, this correlation is spurious.

Restraining from theoretical propositions we could not say whether the causal arrow runs from exports to institutions or vice versa, from institutions to economic performance or vice versa, and from economic performance to exports or vice versa. Without time series data for our institutional variable, we cannot apply the Granger causality test and with no further information at regional, provincial and local level we cannot make use of instrumental variables. Therefore, we cannot know whether we have case a) or case b). Relying on the different theoretical frames presented above and summarized in Table 5, we can assume asymmetric (i.e., set the causal arrows for) relationships as on the graphs in Figure 3. More specifically, we can check for the fitness of cases a) and b), exclude the latter (as in North 1991 which assumes that exports bring institutions, and not the reverse) and accept the 
former: institutions are an intervening variable, that is the causal effect of exports on GDP operates also through business regulations.

Theoretical propositions at stake

Table 5

\begin{tabular}{l|l} 
"North 1955" (Export-base) & Exports bring GDP \\
\hline "North 1981" (Institutional perspective) & Institutions bring GDP \\
\hline "North 1991" & Exports bring institutions
\end{tabular}

In other words, what would matter for China's long-run growth is not just the volume of exports or the "quality" of these exports or the subsidization of investments in new products (see Rodrick 2006 and Herrerias and Orts 2010 among many others): also business regulations are crucial. This would suggest that simplified and less costly ways of implementing existing regulations (such as completing business start-up formalities in a one-stop shop or lower cost bureaucracy) exert an essential role in the sustainability of China's export- oriented model. And this has evident implications at the urban as well as the national levels.

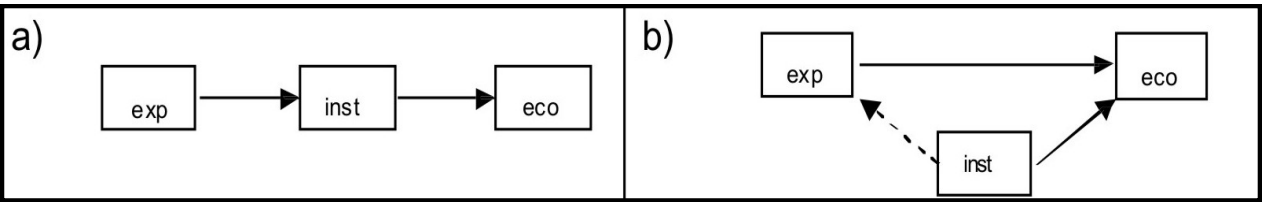

Fig. 3 - Exports and GDP: a spurious correlation?

If we do not rely on any theoretically assumed causal relationships, we need to test a 2SLS model between business regulations (dependent) and exports (independent, instrumented variable) making use of the inverse of closeness to sea of each capital times the number of ports in the related province (closeport) as instrumental variable. In literature several geographical/ecological variables have been used as instruments in investigating the causal relationship between institutions and economic outcomes: settler mortality, population density in 1500 , latitude, landlock area, and so on

Attempting to estimate the causal effect of exports on business regulations, we derive that closeport affects the latter only through its effect on the former. If the instrument only affects business regulations because it affects exports (holding other variables in the model fixed), correlation between the geographical variable and business regulations is evidence that exports cause changes in the business regulatory environment. This instrument has the property that changes in closeport are associated with changes in exports (exp) but do not lead to change in business regulations (inst), aside from the indirect route via exports.

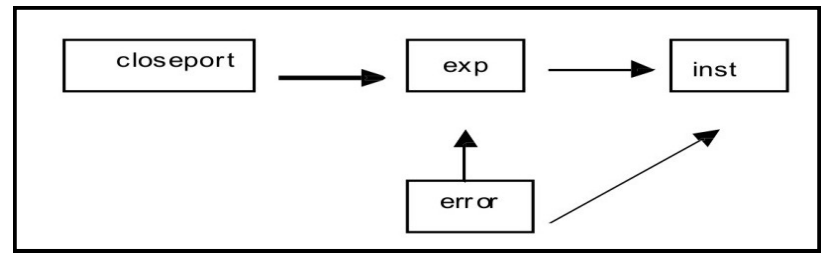

Fig. 4 - Instrumental variable, exports and institutions 
Closeport is associated with exports but not with the error term (u) of the OLS regression model with dependent variable inst and exp as single regressor ${ }^{6}$. Results of the 2SLS regression model are encouraging as shown in table 6 and, despite the very limited number of observed Chinese cities, invite to further empirical investigation.

Table 6

Instrumental variable (2SLS) regression

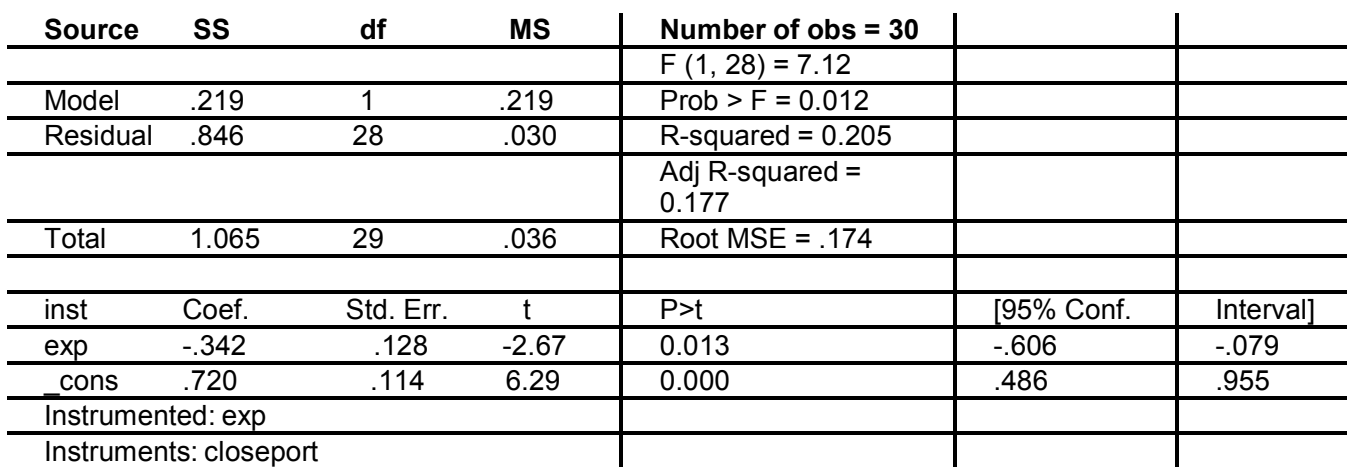

Since urban "essentials" determine regional and national prosperity and growth, cities are fundamental levers, characterised not only in terms of tangible (i.e., transport infrastructures) but also in terms of intangible assets, business regulations and their administrative procedures, as well as human and social capital, etc (on the relevance of institutional capital, knowledge capital and human capital as a driving force of China's economic development see Wang and Hu 2007; on a more general level, see World Bank 2000).

The shape of the fitted lines is interesting: here we refer to figure 2 (b), which combines exports and institutional performance. It appears that business regulations are strongly correlated to local exports, but not with the same intensity everywhere: all cities export, prosper and grow but it seems that in some areas institutions are not one of the factors associated to the competitive advantage or, if present, carry less weight.

Let consider our data on Chinese cities (cross-section) as a time-series in which each data per city represent different steps in the evolution of a benchmark urban area, which changes and develops over time. Let us assume that the values attached to the most developed cities, such as Nanjing and Chongqing, represent the last steps in this urban transformation (replicating the North's reasoning in section 2 on the implications of long distance trade), while the values attached to the least developed areas correspond to its first stages. The result, as seen, are non-linear or "kinked" (linear with discontinuities) curves depicting the relationship between exports and business regulations: there is no one single model applicable to all geographic areas.

From this point of view we suggest that if until recently the benchmark urban area has grown

6) The second assumption excludes the instrument from being a regressor in the model for inst, since if instead inst depended on both exp and closeport and inst is regressed on exp alone then closeport is being absorbed into $u$ so that the instrument will then be correlated with the error. 
based on poor or no business regulations, to continue its development along a sustainable path, it must exploit efficient business regulations. This applies to studies comparing urban as well as country level data, and calls for further theoretical and empirical investigations. Our small sample of Chinese cities shows that there are two clusters: one containing those cities that perform better in economic performance (basically, exports) and business regulations terms, and one that includes those cities that perform less well.

\section{Export-base in Chinese cities (location quotients)}

Table 6

\begin{tabular}{|c|c|c|c|c|c|c|c|c|c|c|c|c|c|c|c|}
\hline Region & City & $\begin{array}{ll}\text { LQ1 } \\
\end{array}$ & LQ2 & LQ3 & LQ4 & LQ5 & LQ6 & LQ7 & LQ8 & LQ9 & LQ10 & LQ11 & LQ12 & LQ13 & LQ14 \\
\hline Anhui & Hefei & 0.75 & 0 & 1.06 & 0.11 & 1.42 & 2.01 & 1.41 & 0.09 & 0.06 & 0.29 & 0.09 & 0.1 & 0.12 & 2.16 \\
\hline Beijing & Beijing & 0.04 & 0.55 & 0.69 & 0.05 & 0.75 & 1.92 & 1.78 & 0.08 & 2.7 & 2.46 & 1.12 & 2.76 & 1.43 & 0.06 \\
\hline Chongqing & Chongqing & 0.08 & 0.27 & 0.94 & 2.38 & 2.16 & 0.06 & 1.18 & 1.92 & 1.1 & 0.4 & 0.08 & 1.01 & 1.42 & 0.09 \\
\hline Fujian & Fuzhou & 0.08 & 0.2 & 1.54 & 1.31 & 0.07 & 0.86 & 0.9 & 1.39 & 1.22 & 0.49 & 0.05 & 0.04 & 1.12 & 1.45 \\
\hline Gansu & Lanzhou & 0.03 & 3.6 & 0.91 & 0.12 & 1.84 & 0.06 & 0.86 & 0.07 & 0.06 & 0.47 & 1.67 & 1.6 & 0.09 & 1.02 \\
\hline Guangdong & Guangzhou & 0.04 & 0.06 & 1.34 & 0.05 & 0.03 & 1.88 & 1.24 & 0.07 & 0.07 & 1.6 & 1.12 & 0.05 & 0.06 & 1.72 \\
\hline Guangxi & Nanning & 8.89 & 0.32 & 0.75 & $\frac{0.03}{1.49}$ & $\frac{0.0 \mathrm{v}}{1.3}$ & 0.08 & 0.08 & $\frac{0.01}{1.81}$ & 1.25 & 0.34 & 1.98 & $\frac{0.05}{1.5}$ & 2.19 & 0.13 \\
\hline Guizhou & Guiyang & 0.74 & 0.14 & 0.98 & 1.83 & 2.88 & 0.03 & 0.1 & 1.29 & 0.14 & 1.41 & 0.08 & 0.07 & 0.08 & 1.69 \\
\hline Hainan & Haikou & 1.66 & 0.32 & 0.03 & 0.16 & 2.2 & 2.4 & 0.1 & 2.25 & 3.45 & 0.64 & 2.57 & 0.12 & 0.23 & 2.41 \\
\hline Heibei & Shiji azhuang & 0.95 & 0.08 & 1.18 & 2.51 & 0.8 & 0.07 & 0.1 & 0.11 & 0.26 & 0.58 & 2.38 & 1.09 & 1.87 & 0.09 \\
\hline Heilongiiang & Harbin & 0.37 & 0.96 & 1.07 & 0.1 & 1.14 & 0.06 & 1.74 & 1.07 & 0.7 & 0.09 & 1.17 & 0.89 & 0.08 & 1.43 \\
\hline He'nang & Zhengzhou & 0.85 & 15.16 & 1.08 & 0.16 & 0.13 & 0.05 & 0.08 & 0.14 & 1.67 & 1.04 & 2.77 & 0.09 & 0.14 & 0.12 \\
\hline Hubei & Wuhan & 4.27 & 0.06 & 0.85 & 1.18 & 2.24 & 0.07 & 1.14 & 0.07 & 0.03 & 0.04 & 0.98 & 1.17 & 0.07 & 1.45 \\
\hline Hu'nan & Changsha & 0.37 & 0.11 & 0.85 & 1.21 & 2.14 & 0.87 & 1.65 & 0.09 & 1.57 & 0.76 & 0.07 & 0.07 & 0.08 & 2.15 \\
\hline Inner Mongolia & Hohhot & 3.43 & 0.29 & 0.05 & 5.45 & 0.05 & 1.52 & 0.08 & 0.23 & 0.61 & 1.6 & 3.93 & 2.58 & 7.24 & 3 \\
\hline Jiangsu & Nanjing & 0.92 & 0.53 & 1.39 & 0.08 & 0.71 & 0.1 & 0.06 & 0.08 & 0.05 & 0.31 & 1.4 & 1.53 & 0.1 & 1.97 \\
\hline Jiangxi & Nanchang & 7.18 & 0 & 1.01 & 1.96 & 2.53 & 0.13 & 0.04 & 1.42 & 0.05 & 0.37 & 0.07 & 0.08 & 2.53 & 0.11 \\
\hline Jilin & Changchun & 2.21 & 1.49 & 0.92 & 1.94 & 0.64 & 0.78 & 1.02 & 0.07 & 1.17 & 0.51 & 1.32 & 1.42 & 2.19 & 1.79 \\
\hline Liaoning & Shenyang & 0.08 & 2.77 & 0.93 & 2.33 & 0.03 & 2.55 & 0.99 & 1.92 & 0.04 & 0.06 & 1.42 & 0.07 & 0.12 & 2.02 \\
\hline Ningxia & Yinchuan & 17.94 & 2.37 & 0.06 & 15.18 & 1.84 & 0.1 & 0.12 & 0.32 & 1.69 & 0.22 & 0.21 & 0.21 & 0.31 & 3.71 \\
\hline Qinghai & Xining & 4.82 & 3.78 & 0.05 & 6.62 & 0.12 & 3.41 & 0.1 & 0.23 & 0.93 & 0.29 & 2.98 & 0.17 & 2.95 & 3.87 \\
\hline Shaan $x i$ & $\mathrm{X}^{\prime}$ 'an & 1.54 & $\frac{10}{3}$ & 1.09 & 1.78 & 0.77 & 0.06 & 1.72 & 0.06 & 0.51 & 1.49 & 0.94 & 2.3 & 0.77 & 0.06 \\
\hline Shandong & Ji'nan & 0.15 & 2.45 & 0.87 & 0.07 & 2.23 & 0.05 & 1.61 & 1.68 & 0.99 & 0.07 & 0.08 & 0.74 & 0.97 & 1.41 \\
\hline Shanghai & Shanghai & 0.56 & 0.02 & 1.27 & 1.11 & 0.02 & 1.84 & 0.06 & 2.42 & 1.3 & 0.06 & 0.82 & 0.07 & 1.27 & 1.72 \\
\hline Shan $x i$ & Taiyuan & 1.68 & 1.42 & 0.11 & 0.2 & 0.12 & 0.23 & 2.5 & 3.24 & 0.8 & 1.73 & 2.8 & 3.85 & 4.1 & 3.22 \\
\hline Sichuan & Chengdu & 0.4 & 0.59 & 0.91 & 0.06 & 3.04 & 0.06 & 1.06 & 1.54 & 0.79 & 0.46 & 0.07 & 0.08 & 1.41 & 0.1 \\
\hline Tianjin & Tianjin & 0.04 & 0.23 & 1.29 & 1.32 & 0.59 & 1.24 & 0.06 & 1.29 & 0.63 & 3.68 & 1.12 & 0.05 & 1.54 & 0.07 \\
\hline Xinjiang & Urumgi & 7.13 & 0.52 & 0.97 & 2.99 & 0.11 & 0.19 & 1.73 & 2.51 & 2.6 & 0.19 & 0.13 & 0.13 & 0.14 & 3.36 \\
\hline Yunnan & Kunming & 0.13 & 2.54 & 0.04 & 1.49 & 2.23 & 2.07 & 1.63 & 1.5 & 0.06 & 0.68 & 1.95 & 1.63 & 1.2 & 1.92 \\
\hline Zhejiang & Hangzhou & 0.2 & 0.17 & 1.46 & 0.05 & 0.06 & 0.93 & 1.04 & 1.69 & 0.05 & 0.44 & 1.19 & 1.1 & 0.06 & 0.08 \\
\hline
\end{tabular}

Source: China Data Online (2010), at chinadataonline.org

\section{References}

ACEMOGLU, D., JOHNSON, S., ROBINSON, J.A. (2001), The Colonial Origins of Comparative Development: An Empirical Investigation, American Economic Review, 91:13691401.

ALDASHEV, G. (2009), Legal institutions, political economy, and development, Oxford Review of Economic Policy, 25, 2: 257-270.

ARDAGNA, S., LUSARDI, A. (2008), Firm Performance and Regulation Explaining International Differences in Entrepreneurship: The Role of Individual Characteristics and Regulatory Constraints, NBER working paper no. 14012.

BEYERS, W.B. (2005), Services and the Changing Economic Base of Regions in the United States, The Service Industries Journal, Vol. 25: 461-476.

BEYERS, W.B., ALVINE, M.J. (1985), Export services in postindustrial society, Papers of the Regional Science Association, 57: 33-45.

BOTERO, J., DJANKOV, S., LA PORTA, R., LOPEZ-DE-SILANES, F. (2004), The regulation of labor, Quarterly Journal of Economics, 119 (4): 1339-1382. 
DE SOTO, H. (1989), The Other Path. The Economic Answer to Terrorism, Harper and Row, New York.

DJANKOV, S., MCLIESCH, C., RAMALHO, R. (2006), Regulation and Growth, Economics Letters, vol. 92, issue 3, 2006: 395-401.

DJANKOV, S., MCLIESH, C., RAMALHO, R. (2004), Growth and the Ease of Doing Business, Working Paper, World Bank, Washington, DC.

DJANKOV, S., LA PORTA, R., LOPEZ-DE-SILANES, F., SHLEIFER, A. (2002), The regulation of entry, Quarterly Journal of Economics, 117 (1): 1-37.

EASTERLY, W., LEVINE, R. (2003), Tropics, Germs, and Crops: How Endowments Influence Economic Development, Journal of Monetary Economics, 50: 3-40. FINANCIAL TIMES (2006), Undoing Business, 6 September 2006.

HALL, R., JONES, C.I. (1999), Why Do Some Countries Produce So Much More Output per Worker than Others?, Quarterly Journal of Economics, 114: 83-116.

HERRERIAS, M.J., ORTS, V. (2010), Is the export-led growth hypothesis enough to account for China's growth?, China \& World Economy, 18, 4: 34-51.

HOOVER, E.M. (1937), Location Theory and the Shoe and Leather Industries, Harvard University Press, Cambridge.

HU, Y., QIU, L.D. (2010), An empirical analysis of contracting by Chinese firms, China Economic Review, 21: 423-431.

JONES, E.L. (1981), The European miracle: Environments, economies and geopolitics in the history of Europe and Asia, Cambridge, Cambridge University Press.

LA PORTA, R., LOPEZ DE SILANES, F., GLAESER, E.L., SHLEIFER, A., DJANKOV, S. (2003), The New Comparative Economics, Journal of Comparative Economics, 31 (4): 595619.

LA PORTA, R., LOPEZ-DE-SILANES, F., SHLEIFER, A. (2006), What works in securities laws? Journal of Finance, 61 (1): 1-32.

LA PORTA, R., LOPEZ-DE-SILVANES, F., SHLEIFER, A., VISHNY, R.W. (1998), Law and Finance, Journal of Political Economy, 106 (6): 1113-1155.

McMILLAN, J., WOODRUFF, C. (1999), Dispute prevention without courts in Vietnam, Journal of Law, Economics \& Organization, 15, 3: 637-658.

NORTH, D.C. (1955), Location Theory and Regional Economic Growth, Journal of Political Economy, LXIII: 243-258. NORTH, D.C. (1981), Structure and Change in Economic History, Norton, New York.

NORTH, D.C. (1987), Institutions, Transaction Costs and Economic Growth, Economic Inquiry, vol. 25(3): 419-428.

NORTH, D.C. (1990), Institutions, Institutional Change and Economic Performance, Cambridge University Press, Cambridge. 112. NORTH, D.C. (1991), Institutions, Journal of Economic Perspectives, vol. 5, no. 1: 97-

NORTH, D.C., THOMAS, R.P. (1973), The rise of the western world: A new economic history, Cambridge, Cambridge University Press.

RODRIK, D. (2003), Growth Strategies, Boston, Harvard University.

RODRIK, D. (2006), What's so special about China's exports?, NBER Working Paper Series, no 11947, available at nber.org.

RODRIK, D., SUBRAMANIAN, A., TREBBI, F. (2004), Institutions Rule: The Primacy of Institutions over Geography and Integration in Economic Development, Journal of Economic Growth, 9(2): 131-165.

STEL, A., STOREY, D., THURIK, A. (2007), The Effect of Business Regulations on Nascent and Young Business Entrepreneurship, Small Business Economics, 28, 2: 171186. 
WANG, Y., HU, A. (2007), Multiple forces driving China's economic development: a new analytical framework, China \& World Economy, 15, 3: 103-120.

WORLD BANK (2000), The Quality of Growth, The World Bank and Oxford University Press, Washington, D.C.

WORLD BANK / INTERNATIONAL FINANCE CORPORATION (2006), Doing Business in 2006: Creating Jobs, Washington, D.C.

WORLD BANK / INTERNATIONAL FINANCE CORPORATION (2008), Doing Business in China 2008, Washington, D.C.

Initial submission, March 29, 2011

Revised submission, April 15, 2011

Final acceptance, April 28, 2011

Correspondence: University of Chieti Pescara, Viale Pindaro 42, Pescara, Italy.

E-mail: amarra@unich.it; carlei@unich.it 
